\title{
The current situation of secondary school librarians in Bangladesh: A study
}

\section{Zakir Hossain}

https://orcid.org/0000-0001-7095-9792 amity.du@gmail.com / www.theresearchtl.net

Teacher-Librarian/ IASL Director for International Schools Inter-Community School, Zurich

The purpose of this study is to understand the present status of the secondary school librarians in Bangladesh. In general, it is found that although librarianship is not a new concept in Bangladesh, the development of school libraries and to create qualified school library professionals has been slow due to lack of government initiative. Many schools, where there are libraries and librarians, resources and services are minimal and school librarians are not considered teaching staff.

This study derived significant findings which could be used to understand the reality of secondary school libraries and librarians in Bangladesh. The recommendations could also be used to overcome practical issues which may negatively affect school library development in Bangladesh.

Keywords: school library; school librarian; secondary school; middle school librarian; school library management; Bangladesh

\section{Introduction}

$\mathrm{S}$ chool libraries around the globe, in their many forms, share a common purpose: the enhancement of "teaching and learning for all." According to IFLA/UNESCO School Library Manifesto (IFLA, 1999), “The school library equips 2 students with life-long learning skills and develops the imagination, enabling them to live as responsible citizens." Research claims that access to reading materials is a critical factor in developing enthusiastic and skilled readers and there is a direct link between reading level and learning results (Krashen, 2004). 
There is a good number of research *[For example, see LRS (2015) School Libraries Impact Studies in the USA and Williams, Wavell, C., and Morrison (2013) in the United Kingdom] correlated to the positive impact on student accomplishment of well-resourced school libraries staffed with professional school librarians (Gretes, 2013; Scholastic, 2016). While most of the research has been carried out in the United States and Australia, a recent UK national study suggests that children who use the school library have a higher reading score; they are also more likely to enjoy reading, to see themselves as good readers and are more motivated to read (National Literacy Trust, 2017).

Role of libraries is highly valued in Bangladesh. According to a British Council report (2015), almost everyone who goes to library thinks that libraries are highly valuable for society. Bangladesh Government, related ministries, directorate, departments and non-government and non-profit organizations took initiatives aim to make use of the country's existing libraries to craft opportunities for children and their families to advance access to more reading materials and begin to associate reading with enjoyment (Katz, 2016). Since 2010 the government has taken the action of reorganizing the system of education to meet the challenges of the $21 \mathrm{st}$ century, and as part of the implementation of National Education Policy 2010, Ministry of Education (MoE), included Assistant Librarian posts for secondary schools in its Manpower Structure 2010.

\section{Background}

\section{Secondary Education in Bangladesh}

There are around 333 government and 16,109 non-government secondary schools in Bangladesh (MoE, 2016). The government of Bangladesh provides free education up to HSC (grade-12) for the female along with the stipend and the government has recently announced that it will extend free and compulsory primary education to all students through grade 8 (World Bank, 2016). At the secondary level the gross enrolment was 57 percent in 2008, representing a three-fold increase since 1980. Much of the gain at the secondary level was due to a seven-fold increase in girls' enrolment since 1980 (UNESCO, 2012). Literacy rate among the young adult populations estimated to have reached the 78.63 percent mark (MoPME, 2015). Adult literacy rate reached 
59.8\% in 2010 (BBS, 2011). Furthermore, Bangladesh has achieved gender parity in access, in addition to dramatic decreases in disparities between the highest and lowest consumption quintiles at both the primary and secondary levels (World Bank, 2016).

Regardless of significant improvements in girls' and women's access to secondary education, UNESCO 2012 report claimed that overall quality remains a challenge in Bangladesh. Repetition (the number of times students repeat grades) and dropout rates are still substantial in Bangladesh and only 50 percent of the students who enroll in first grade reach grade 10. Government spending on education as a share of the gross domestic product is around 2 percent, the second lowest in South Asia, and lowers than in most other countries at similar levels of development (World Bank, 2016). Most children in Bangladesh only have access to textbooks at school; additional materials like 3 storybooks and educational games are rare. A recent study (Katz, 2016) found that more than $40 \%$ of children don't have books other than religious texts at home.

\section{Secondary school librarians in Bangladesh}

To ensure access to resources besides textbook and to promote reading secondary schools and madrasahs supposed to be equipped with libraries and librarians. Since 2010, the number of secondary school librarians in Bangladesh is moving towards a period of rapid growth, and so far about 9,000 Assistant Librarians (MPO) recruited and more (about 20,000) Assistant Librarian cum Cataloger will be hired gradually in secondary schools and madrasahs (MoE website and Personal communication [AFM Kamrul Hasan], 25th March 2018). In support to Digital Bangladesh agenda, the government has prepared the Digital Bangladesh Strategies paper and in the process of a master plan for ICT in Education and libraries of all types is included in this plan (UNESCO, 2013). To emphasize, the importance of books, reading, libraries and librarians in the everyday lives, the current government declared February 5th as 'National Library Day' and from 2018 compulsory library lesson has included in secondary school lessons (MoE, 2017).

\footnotetext{
International Association of School Librarianship
} https://www.iasl-online.org/ 
To inculcate reading at all levels and to develop secondary students reading habits and stimulates school libraries, the then government started a nation-wide project 'Developing the Reading Habit (DRH)' that carried out from July 2008 to December 2017 in 250 Upazila at around 12,117 educational institutes secondary schools across the country. The project was financed by the IDA (International Development Agency) and Bangladesh Government. The objective was to set-up of a reading program at the school level for grades 6-10 students keeping track with the school routine after or before school hours or during holidays. The said project was directly monitored and implemented by the Secondary Education Quality and Access Enhancement Project (SEQAEP) under the Directorate of Secondary and Higher Education (DSHE) of MoE Bangladesh. There were around 82, 57,336 students involved in the project and more than 6.5 million fiction and non-fiction books were distributed to the participated students, schools and libraries (SEQAEP Newsletter).

Developing the Reading Habit project encompassed the followings activities (SEQAEP, 2015 and DSHE, 2015):

- Provision of 192 copies of age and ability appropriate books for each project school;

- Storage facilities for books (Shelve/Almirrah/ Trunk provided on the basis of requirement of the project school);

- Training provided to 6,669 school librarian and library-in-charge as Reading Program Organizer for effective operation of the library as well as reading program (DSHE, 2015);

- Simple test on knowledge earned by the students on prescribed books will be conducted at the end of the academic year;

- $16,62,000$ Book Prize/Award incentives were given to the students selected on the basis of some criteria, through a ceremony at the Upazila level (DSHE, 2015);

To form a solid school library profession in Bangladesh, School Library Association of Bangladesh (SLABD) was established in March 2014 (the then Bangladesh Assistant Librarian Association-BALA). 4

Problem Statement 
Although librarianship is not a new concept to Bangladeshis, the development of school libraries and to create qualified school library professionals has been slow due to lack of government and non-government initiatives. In Bangladesh, there is a very few government and non-government specialized organizations that are fostering reading habits of the young generation (SEQAEP, 2016). According to a Room to Read report, in Bangladesh access to resources is a problem, with no formal library system in schools (Room to Read, 2017). People in Bangladesh have a mixed perception about the libraries and librarians. About 63 percent users think Bangladeshi libraries are not technologically modern and library services are not creative enough. Nonetheless, most of the users expressed that librarians have skills to meet their demand (British Council, 2015). Among the 333 government and 16,109 non-government secondary schools in Bangladesh there are only 9,000 (approx.) schools have libraries of which many of them do not have qualified school librarians (Personal communication [Mahbub Alam] March 27 2018).

With various existing challenges, since January 2017, secondary school librarians in Bangladesh have been encountered an additional challenge which remarkably impacts their social values. According to a 2017 Ordinance (01/01/2017) directed by the Secondary and Higher Secondary Education Board (SHSEB), Dhaka; (part of Bangladesh Gadget-Additional issue 2016) nongovernment school and college librarians/assistant librarians included as non-teaching staff which is contradictory to the prior ordinances and amendments.

\section{Objective of the Study}

The primary objective of the study is to understand the current situation and trends of secondary school librarians in Bangladesh. The study aims to:

- discuss current government initiatives to develop secondary school librarians;

- identify the problems that challenge secondary school librarians and formulate proposals for development; 


\section{Literature Review}

The central function of a school library is to provide physical and intellectual access to information, knowledge and ideas. The richness and quality of a school library program primarily depend upon the workforce available within and beyond the school library. Therefore, to meet the teaching and learning needs of a school community, it is essential to have a welltrained and highly motivated proactive staff. According to IFLA School Library Guidelines (2015), "Because the role of school libraries is to facilitate teaching and learning, the services and activities of school libraries need to be under the direction of professional staff with the same level of education and preparation as classroom teachers."

The credentials of school librarians vary across the continents and may include librarians with or without teacher training and librarians with training in other library domains. Smith (2001) listed that studies of library systems in the USA at Alaska, Colorado, Oregon, and Pennsylvania found that: i librarians have a positive effect on student achievement, ii) Library media specialists (school librarian) serve as both teachers of students and in-service providers for teachers.

A school librarian is not only responsible for the school's physical learning but also digital learning space where reading, inquiry, research, thinking, imagination, and creativity are the center of teaching and learning. This role is known by several terms such as school librarian, school library media specialist, teacher librarian, professeurs documentalistes (in France) but the term 'school librarian' is the most commonly used (Hossain, 2017). These days, school librarians are considered the frontier of the Multi-literacy effort at schools. Sinko (2013) explained multiliteracy includes the traditional reading and writing skills, as well as the so-called new literacies such as visual literacy, digital literacy, information literacy and media literacy. Neil Gaiman puts it nicely when he says, "Google can bring you back 10000 answers, but a librarian gives you the right one". Sally Dring (2014) went further and argued that "don't overlook your school librarian; they're the unsung heroes of literacy."

Staffing structures for school libraries also change subject to the local context, which is influenced by legislation, economic development and educational infrastructure. However, more than 50 years of international research on school librarianship collectively (see, for example, 
Haycock, 1992, in LRS (2015) School Libraries Impact Studies (www.lrs.org/datatools/schoollibraries/impact-studies) directs that a school librarian necessitates formal education in school librarianship and teaching in the classroom setting that provides the professional expertise required for the complex roles of instruction, reading and literacy development, school library management, collaboration with teaching staff, and engagement with the educational community (IFLA SLG, 2015). School librarians offer the best possible resources to their patrons, within limited budgets. There is much more than books in a school library; it is a hybrid environment where individual and group learning takes place.

Although socio-economic factors continue to be the strongest predictor of academic success, school library characteristics may account for up to 8 percent of the variance in reading-related test scores (Smith, 2001). As Hossain (2015) stated that it is sometimes considered that librarians and teachers by their professional education already have the necessary skills to engage in reader development. Effective librarians perform a variety of tasks, including student instruction and teacher professional development. In their approach, school librarians should be pragmatic and flexible when providing reading material to users, supporting the individual preferences of readers, and accepting their rights to choose what users want to read. A school librarian should also support teachers in their work with classroom reading to meet school, local and national standards, for example, helping out with the recommendation of books suitable for reading projects and of books that support the state or national language standards.

\section{Methodology}

This study is qualitative and quantitative to ensure best possible outcomes. Besides surveying secondary school librarians online, to understand their current situation, the nature of their work and the impacts of different government decisions to school librarians, comprehensive literature in English and Bengali available online has been consulted. To get clear viewpoints and gather relevant information for this study, various check-in questions posted on School Library Association of Bangladesh (SLABD) Facebook group and personal communications have also 
been made with the SLABD committee members. When the researcher utilizes secondary data, he had to look into 6 various sources from where the original piece derived. In this case, he is indeed not confronted with the problems that are usually associated with the collection of original data as secondary data may either be published data or unpublished data (Kothari 1970). From the online survey, a total of $75(n=75)$ responses received of which 90.5 percent male and 9.5 percent female. Geographically, participants represented 27 districts (provinces) out of 64 in Bangladesh.

Table 1. Frequency distribution by gender

\begin{tabular}{|c|c|c|}
\hline Gender & No. & \% \\
\hline Male & 68 & 90.7 \\
\hline Female & 7 & 9.3 \\
\hline Total (n) & 75 & 100 \\
\hline
\end{tabular}

Profiles of the respondent comprising 86.1 percent 'secondary school librarian', followed by both 5.6 percent 'college librarian' and 5.6 percent 'school and college librarian' (K-12/primary through higher secondary), 1.4 percent 'madrasah librarian' and 1.4 percent “others'. Half (50\%) of the respondents are in between 30 to 35 years old. The respondents' demographic information also revealed the respondents' years of working experience and it is understood that a vast majority school librarians in Bangladesh are in their early year career level.

Regarding educational qualifications, more than half of the respondents have a Master's degree in various disciplines. (e.g., library and information science-LIS) most of theschool librarians have LIS Diploma (74.7 percent).

The actual questionnaire link posted on SLABD Facebook group in early January 2018 and several follow-up posts were posted. The responses were automatically recorded and tabulated on Google Form and analyzed. Some respondents did not answer all questions, and the missing responses are reflected in the varying sample size (n) values. 


\section{Results}

Most of the secondary school librarians are well qualified. In addition to their general educational qualification (Bachelor's Degree), all of them have a LIS degree or diploma. Besides library related task, a vast majority $(90.5 \%)$ of them teach various subjects (e.g., Bengali, English, Sciences and Social Sciences) in the classroom. However, 70.3 percent respondent school librarians indicated that they are not considered as teaching staff and surprisingly many of them are not sure whether they are teaching or non-teaching staff.

Table 2. Frequency distribution by work status $(n=75)$

\begin{tabular}{|l|l|l|l|l|}
\hline Teaching Staff & Yes & No & Not sure & Total \\
\hline No. & 12 & 53 & 10 & 75 \\
\hline$\%$ & 16 & 70.7 & 13.3 & 100 \\
\hline
\end{tabular}

School librarians in Bangladesh face various challenges. The professional development (PD) opportunity for Bangladeshi school librarians is not sufficient rather alarming. 71.2 percent respondents indicated that they did not receive any PD in last two years and 61.7 percent said among others (see Chat 1) it is (no PD) one of the major challenges in their profession.

Chat 1. Workplace challenges of Bangladeshi School Librarians.

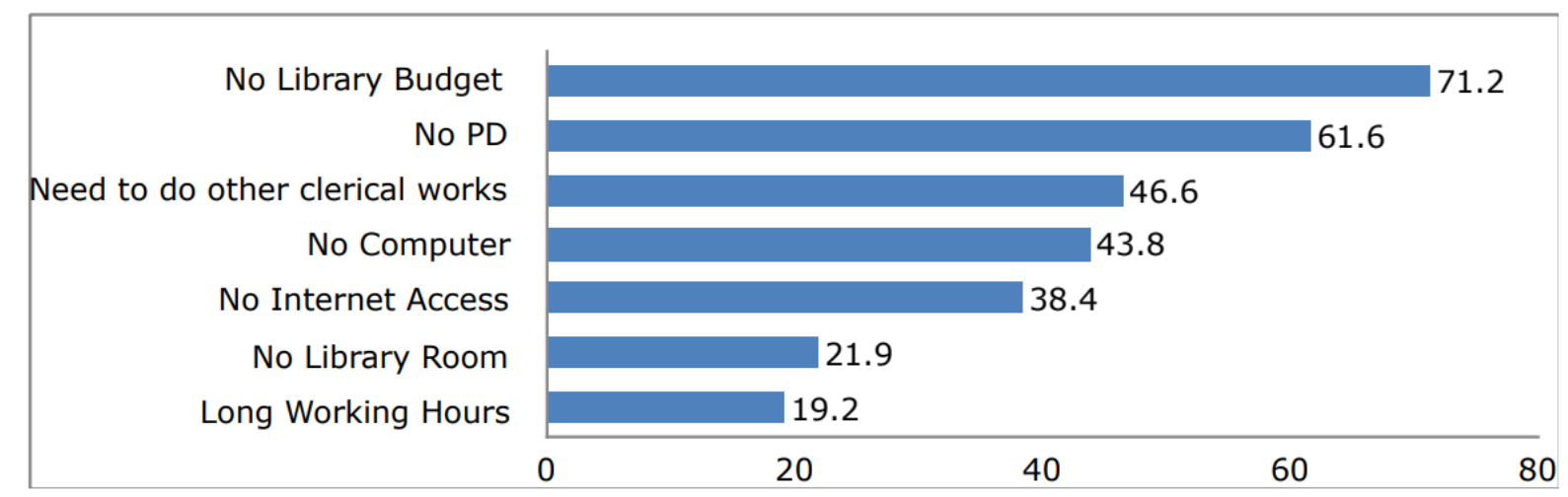

International Association of School Librarianship https://www.iasl-online.org/ 
However, to be up-to-dated professionally, a good number of school librarians' usage various learning platforms such as Facebook, Facebook groups and other 'online learning platforms' via Internet. Surprisingly, 85.3 percent respondents specified that they learn professional things on the local, regional and international library professional groups on Facebook. A vast majority $(90.5 \%)$ of Bangladeshi school librarians (BDSL) think that Facebook group can be used as a microlearning professional development platform.

Chat 2. Alternative PD/Professional learning platforms usage by BDSL.

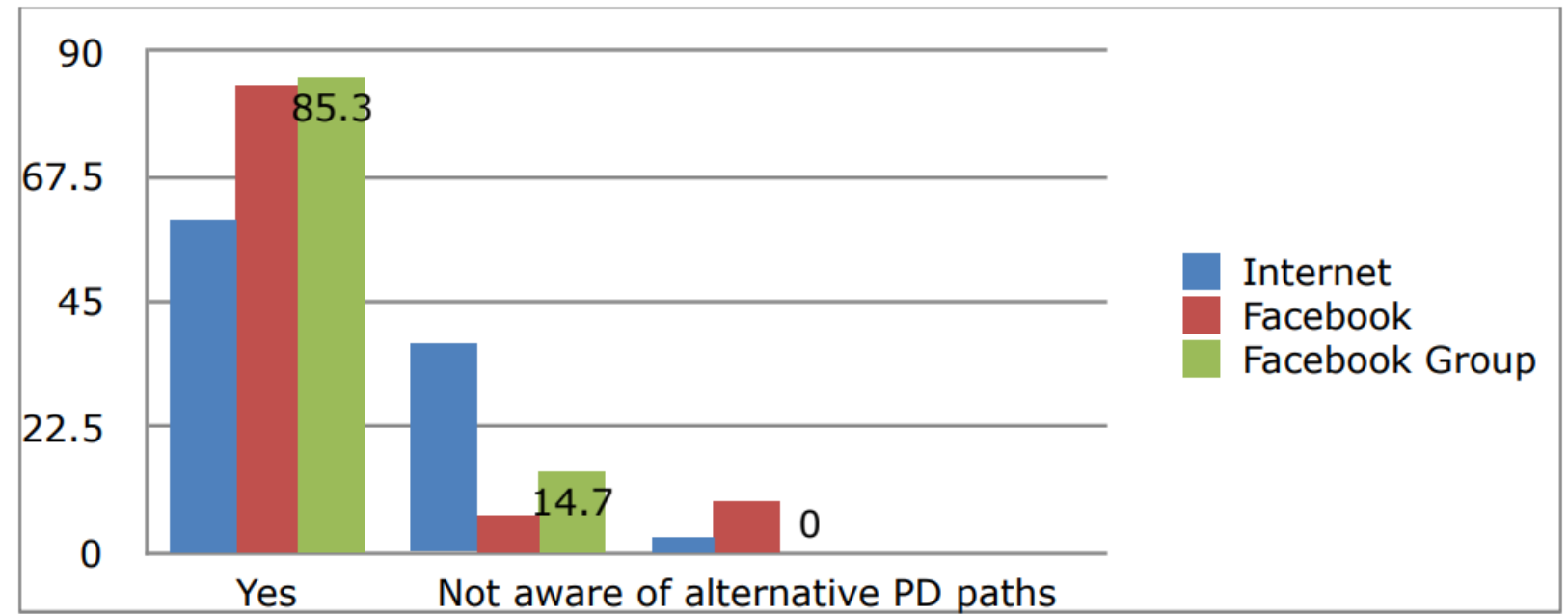

In March (3rd) 2018, four years later of its establishment, the School Library Association of Bangladesh (SLABD) formed its first-ever national committee and at the same time (March 27th) it has taken a partner membership from the International Association of School Librarianship (IASL) - a world body of school librarians. As a partner member of the IASL, it is expected that SLABD will receive necessary support such as professional development training, conference attendance and policy resources. The author himself is dedicated to bridging the organizations (IASL \& SLABD) in his capacity as an IASL Director for International Schools (Zone-9) and Advisor of SLABD.

Finding and discussion 
From literature review and through personal communication, it is learned that besides developed countries (USA, Canada, Australia, New Zealand, Singapore, etc.), many developing countries in Asia such as Sri Lanka, India, Malaysia and Indonesia, qualified school librarians are considered teaching staff and enjoy equal benefits such as salary, professional development and annual increment as teachers. In India particularly, school librarians enjoy teaching staff status in the schools run by the central government of India and get equal pay (Anandabazar, Sept. 5, 2015 [see https://goo.gl/FuxSgN]). According to IFLA School Library Guidelines (2015), in Portugal, since 2009, the school librarian (professor bibliotecário) who has specialized in librarianship is considering a school teacher. In France, who work in junior high schools and high schools as librarians (professeurs documentalistes) are recruited and trained at the same education level and status as teachers.

The 2017 Ordinance (01/01/2017) from the then Chairman of Secondary and Higher Secondary Education Board (SHSEB), Dhaka is contradictory with previous ordinances and amendments and required further consideration. For example, according to the MoE 2013 (05/05/2013) (MoE website) amendment namely "Non-Government education institute (school, college and madrasah) class 3rd and 4th employees job description-2012 partial amendment), the assistant librarian did not list as class 3rd or 4th employee which also indicates they are teaching staff. Furthermore, according to a Bangladesh Government Ordinance, Order No. 7002/1 / Civil-1, 8/10/83, librarians had been shown as teaching staff. Dr. Kudrat-e-Khuda Commission Report 1974, mentioned that "Equally qualified librarian and library staff should be recognized as teachers regarding the status and remuneration”. The statute of Dhaka University 1983 has shown librarians as a teacher of its affiliated colleges. The same consistency has also been maintained in the National University Bangladesh (NUB) Constitution (Pervin, n.d.). Finally, as far National Education Policy 2010 (chapter 20) (see https://goo.gl/AbojSz], librarians have been mentioned as the center of learning in the educational institute and the librarian and assistant librarians of school and college have been told to determine the proper status.

International Association of School Librarianship https://www.iasl-online.org/ 
Since there is no other post except teachers and non-teachers at the MPO Education Institute of Bangladesh, and salary allowances, festival allowances and retirement allowance also comes in the name of teaching and nonteaching staff and as per the revised notification dated 5/5/2013, the assistant librarians are teaching staff and the Gazette (01/01/2017) issued by the Chairman of the SHSEB, Dhaka is contrary to the MoE Manpower Structure and 2013 Bangladesh Gadget (Amendment) requires further amendment.

Findings from the literature review, it is understood that:

- In Bangladesh, teaching and learning process in schools do not encourage the usage of libraries let alone treat school libraries as an integral part of school education.

- The importance of school libraries has been, for the longest time, overlooked by policymakers.

- This is evident from the fact that libraries mainly school libraries, insofar as they function as hubs of knowledge, education, and entertainment, are mostly absent from Bangladesh's national consciousness.

- Having equal or even higher educational qualifications, many school librarians are not considered as teaching staff and their social value is often not acknowledged. ! Library and Information Science (LIS) education of the country does not offer school library/teacherlibrarianship focused course/program.

- A very few literature had published on Bangladesh school library and librarians development issues.

- Among the 333 government and 16,109 non-government secondary schools, there are around 9,000 schools have libraries and the collections are mostly out of date (Alam, M. (2018, March 27, Facebook messenger.) and services are minimal.

- Usually, in most of the schools where there is no school librarian, the library is only opened during the vacant hour of the librarian-in-charge (teacher).

- Generally, the school library is considered as the last item on the school priority list and there is no regular provision for libraries in the annual budget.

- School libraries, where they exist, are usually used as free time space; these are not embedded in teaching and learning system. 
- Although most of the school librarians are teaching in the classroom and have pedagogical skills they are not allowed to contribute to the curriculum.

- Where there are no school librarians, non-qualified and less active staffs are in-charges of the school libraries which disservice the community and provide an inappropriate message about school libraries and librarians.

- Teachers are reluctant to cooperate and collaborate with the school librarians.

- Schools where there are libraries, there is no selection policy and no one is responsible for selecting or suggesting books for the library except the headmaster or headmistress means there is no community involvement with the library or for book selection.

\section{Propositions for elevating school librarianship in Bangladesh}

\section{Define school librarian roles}

The existence of school libraries depends on educated and competent school librarians. It is said that if there is no trained school librarian, then there is no active school library program. Concerned authorities of Bangladesh should be defined the roles of a professional school librarian such as instructional (i.e., literacy and reading promotion, support inquiry and research), library management (e.g., cataloging, classification, resource acquisition and library service promotion); leadership responsibility such as collaboration with teachers and community engagement. The government of Bangladesh has to ensure qualified school librarians are as equal as teacher and they should be treating as teaching staff. All school library staff should also understand their roles and responsibilities to work with library policies, including those related to equity of access, right to privacy, and right to know for all library users.

\section{Improve school librarians' ICT skills through continuous PD}

ICT knowledge and skills are essential for libraries and librarians to form communities, disseminate information, collaborate, converse and create content anywhere and anytime (Bailie, 
2015 and Hossain, 2016). Connecting with users wherever they are is the key to maintaining the relevance of library services (Hossain, 2016). It is no longer enough to wait for users to walk through the library door before offering a service. In Bangladesh, it is essential to streamline the existing ICT training project for the secondary school librarians across the country and the current government project such as a2i (access to information) Digital Centers and District Youth Development centers can be used as training venues.

\section{Commence school librarianship specialized program at the university level}

School librarianship requires both pedagogical and library management knowledge. There is a need to teach those related skills including information and digital literacy to all LIS students who are planning to work in school libraries (Udina, 2013). Developed countries such as Australia, USA, Canada, Singapore and France offer mainstream courses and programs in school librarianship to build a skilled workforce. Unfortunately, there are no such course or program offers in Bangladeshi universities that focus on school librarianship. It is suggested that Bangladeshi Library and Information Management Schools (LIMS) should be included courses/programs in their curriculum related to school librarianship/Teacher-Librarianship or at very least offer certificate/diploma courses in school librarianship. To exchange and to share professional knowledge with teachers and students, LIMS may invite expert and expatriate school library professionals who currently work in renowned national and international schools in Bangladesh as guest speakers or lecturers.

\section{Strengthen School Library Association of Bangladesh}

The School Library Association of Bangladesh (SLABD) should be an essential player in promoting school library services and to increase the understanding of the role of libraries and librarians in society and national development. School librarians should also be more dynamic in their connection with information seekers. The SLABD should boost national, regional and international cooperation and collaboration with the Library Association of Bangladesh (LAB), BALID, IASL and IFLA. 


\section{Conclusion}

The importance of school libraries cannot be overstated as cruxes of knowledge to the young minds. They are, in fact, an almost necessary and complementary element to any robust education system, and it is good that this fact is finally being noticed in Bangladesh. A National Library Day is the first step, the next step is to make sure there are enough high-quality library facilities, and that they work in harmony with the education system. This study exposed that school libraries are not in a decent situation as regards their services and school librarians are facing considerable challenges in their workplaces. Based on the study findings and from author's experience several recommendations were proposed for improving the school library sector so do increasing the librarianship literacy and competency of Bangladeshi school library professionals.

\section{References}

Bangladesh Bureau of Statistics (BBS). 2011. Report on Bangladesh Literacy Survey 2010. Dhaka.

Das, Ratan K. 2018. The Librarian Times. Http://www.thelibrariantimes.com, 29 Apr. 2018, www.thelibrariantimes.com/wp-content/uploads/2018/04/The_Librarian_Times_V_03_Issue_13_20180429.pdf.

Directorate of Secondary and Higher Education (DSHE). 2015. Semi-annual Monitoring Report (July - December 2015). Ministry of Education Bangladesh. Available at: https://goo.gl/7Nuzac [Accessed 28 Mar. 2018].

Dring, S., 2004. Don't Overlook Your School Librarian; They're the Unsung Heroes of Literacy. The Guardian, 18 Sept. 2014. Available at: www.theguardian.com/teachernetwork/teacher-blog/2014/sep/18/school-librarian-literacysupport-teacher-students [Accessed 19 Mar. 2018].

Godoli Bela[M.A. Kashem). 2014 Jan, 1. যে সব কারনে /यুক্তিতে স্কুল-কলেজে গ্রন্থাগারিক ও সহকারী গ্রন্থাগারিকদেরকে শিক্ষক হিসেবে গণ্য করা উচিত ... [Trans.: The reasons why school and college librarians and assistant 
librarians should be considered as teachers] [Facebook update]. Available at: https://www.facebook.com/groups/1890012784550026/permalink/1982004092017561/ [Accessed 22 Mar. 2018].

Gretes, F., 2013. School library impact studies: A review of findings and guide to sources. Harry \& Jeanette Weinberg Foundation.

Hossain, Z., 2015. Building a learning society using library: Vietnam perspective. Asia Pacific Journal of Libraryand Information Science, 4(1). Available at: https://apjlis.msu.ac.th/index.php/APJLIS/article/view/138 [Accessed 19 Mar. 2018].

Hossain, Z., 2016. Towards a lifelong learning society through reading promotion: Opportunities and challenges for libraries and community learning centres in Viet Nam. International Review of Education, 62(2), pp.205-219.

Hossain, Z., 2017. Professional Development via Facebook Group: Perception of School Librarians. In InternationalAssociation of School Librarianship. Selected Papers from the... Annual Conference, pp.142-154.

International Federation of Library Associations and Institutions (IFLA),1999. IFLA -IFLA/UNESCO School Library Manifesto 1999. [online] Available at: https://www.ifla.org/publications/iflaunesco-school-librarymanifesto-1999 [Accessed 6 Mar. 2018].

Krashen, S.D., 2004. The power of reading: Insights from the research: Insights from the research. ABC-CLIO. Available at: https://goo.gl/5UM33B [Accessed 6 Mar. 2018].

Sinko,P., 2013. School Libraries in Finland: The heart of school seldom beats. Scandinavian Library Quarterly, introductory issue (1).

Katz, A., 2016. How Libraries in Bangladesh Are Creating a Culture of Reading Beyond the Classroom. Beyond Access Bangladesh. Available at: beyondaccess.net/2016/04/04/howlibraries-in-bangladesh-are-creating-a-cultureof-reading-beyond-the-classroom/ [Accessed 19 Mar. 2018].

Ministry of Education Bangladesh (MoE) [SEQEP], 2016. About Directorate of Secondary and Higher Education.

Ministry of Education Bangladesh. Available at: https://goo.gl/qRa7vt [Accessed 12 Mar. 2018].

Ministry of Primary and Mass Education (MoPME). 2015. Education for All 2015 National Review-Bangladesh. Available at http://unesdoc.unesco.org/images/0023/002305/230507e.pdf [Access 1Mar. 2018].

National Literacy Trust (NLT) UK, 2017. School Libraries in the UK: the Current Situation National Literacy Trust - Medium. National Literacy Trust UK. Available at: https://medium.com/national-literacy-trust/schoollibraries-in-the-uk-the-current-situation83e9733107fd [Accessed 13 Feb. 2018]. 
Pervin, M. (n.d.). কলেজ-গ্রন্থাগারিকও শিক্ষক [Trans.: Indeed College Librarians are teachers']. [online] ittefaq.com.bd. Available at: http://archive.ittefaq.com.bd/index.php?ref=MjBfMTJfMDlfMTJfMV8xOF8xXzIzNjE\% 3D [Accessed 19 Mar. 2018].

Secondary Education Quality and Access Enhancement Project (SEQAEP), 2017. SEQAEP Newsletter- (SEQAEP Barta-Bengali Version), April (9). Available at http://www.seqaep.gov.bd/files/SEQAEP_V-9_2017.pdf [Accessed 26 Mar. 2018]

Scholastic, 2016. School libraries work! A compendium of research supporting the effectiveness of school libraries. Available at www.scholastic.com/slw2016 [Accessed 19 Mar. 2018].

SEQAEP. 2016. Developing the Reading Habit' report by Secondary Education Quality and Access Enhancement Project. Available at http://www.seqaep.gov.bd/bsk.php [Accessed 25 Mar. 2018]

Smith, E. G., 2001. Texas school libraries: Standards, resources, services, and students' performance. Austin, TX: Texas State Library and Archives Commission. Available at: http://www.tsl.state.tx.us/ld/pubs/schlibsurvey/survey.pdf [Accessed Aug 11, 2017].

UNESCO, 2012. UNESCO Country Programming Document for Bangladesh 2012-2016. UNESCO Office in Dhaka. Available at: http://unesdoc.unesco.org/images/0021/002168/216874E.pdf [Accessed 23 Feb. 2018].

World Bank, 2016. Bangladesh: Ensuring Education for All Bangladeshis. [online] Available at: http://www.worldbank.org/en/results/2016/10/07/ensuring-education-for-all-bangladeshis [Accessed 6 Apr. 2018]. 